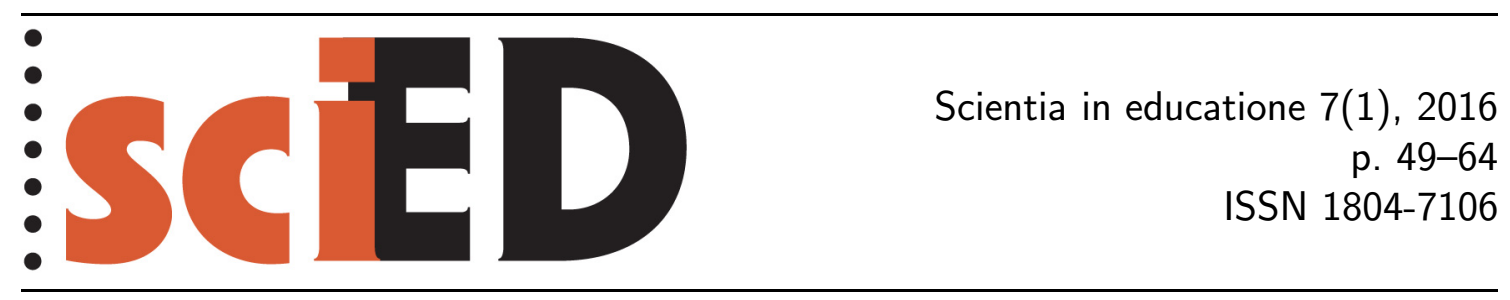

\title{
Typy vzdělávacích komiksů a analýza jejich edukačního potenciálu pro přírodovědnou výuku
}

\author{
Eva Trnová, Tomáš Janko, Josef Trna, Karolína Pešková
}

\begin{abstract}
Abstrakt
Komiksové př́iběhy jsou tradičně vnímány jako specifické populární médium. Vzhledem $\mathrm{k}$ jejich oblíbenosti a srozumitelnosti pro dospívající je jim však pozornost stále častěji věnována i v oblasti přírodovědného vzdělávání. Důležitým aspektem je v tomto ohledu nejen obsah komiksů, ale také jejich výrazové prostředky. Cílem studie je přispět ke konkretizaci edukačního potenciálu komiksů a naznačit způsoby jejich pedagogického využití v kontextu motivace a poznávacích charakteristik současné NET-generace žáků. Jádro studie představuje analýza ukázek vzdělávacích komiksů s př́rodovědnou tématikou, jež se uplatňují při transformování prŕrodovědných konceptů do lépe uchopitelné podoby. Nejdříve je čtenář v obecné rovině seznamován s přínosem komiksů vzhledem $\mathrm{k}$ učebním návykům současných žáků. Následně jsou objasňovány vlastnosti vzdělávacího komiksu a podrobněji vysvětlováno jeho fungování jako didaktického prostředku. V závěru studie jsou na základě zjištěných poznatků vyvozována didaktická doporučení a popisovány př́klady efektivního využití vzdělávacích komiksů v přírodovědné výuce.
\end{abstract}

Klíčová slova: komiksy, konektivismus, Net-generace, přírodovědné vzdělávání, STEM vyučovací předměty, vzdělávací komiksy.

\section{The Types of Educational Comics and Analysis of Their Educational Potential for Science Instruction}

\begin{abstract}
Traditionally, comics are perceived as a specific popular medium. Thanks to their popularity and understandability for adolescents, they are nowadays paid increasing attention even in the domain of science education. In this respect, an important aspect of the comics is their content as well as their means of expression. This study aims to explore the educational potential of the medium and to suggest ways of its beneficial educational use for the contemporary NET-generation of students. Based on the selected examples, educational comics are analyzed as means supporting the transformation of scientific educational concepts to a more understandable form. First, the reader is familiarized with the benefits of comics with respect to the educational needs of the current generation of students. Further, the qualities and functioning of comics as educational means are explained. Finally, recommendations for the effective use of comics in science instruction are suggested.
\end{abstract}

Key words: comics, connectivism, educational comics, Net-generation, science education, STEM school subjects. 
Přírodní vědy, technika a matematika (dále jen $\mathrm{STEM}^{1}$ ) v současnosti čelí novým výzvám. Pokrok v oblasti přírodovědného poznání umožňuje stále hlubší pronikání k podstatě objektů a jevů. Dostupné poznatky se ale díky tomu stávají více komplikované a při komunikování méně srozumitelné. Tato situace se promítá i do roviny školního vzdělávání. Přrírodovědné předměty a matematika jsou přes svou objasňující povahu stále vnímány jako poměrně obtížné. Mnozí žáci se navíc domnívají, že přrírodovědné učivo není pro jejich každodenní život důležité. Přistupují k němu proto rezervovaně či dokonce odmítavě. Učitelé se s touto skutečností ve výuce vypořádávají, avšak zpravidla bez toho, aby měli $\mathrm{k}$ dispozici odborně podložený postup $^{2}$. Obvykle se proto snaží výuku obměnit inovativními edukačními metodami, formami či prostředky (aktuálně např. konstruktivistickými), které do centra výuky staví žáka, jeho zájmy a zpơsoby myšlení či každodenní zkušenosti. Zároveň ale umožňují, aby výuka zůstala zábavná (např. IBSE, blended learning ${ }^{3}$ ). Takovéto přístupy nicméně kladou na učící se žáky nároky, zejména pokud jde o autonomii a seberegulaci. V praxi jsou proto potřeba výukové metody, formy a prostředky, které by žáky motivovaly a vzbuzovaly u nich hlubší zájem o přírodní jevy a jejich zákonitosti. Cílem studie je představit čtenáři specifické didaktické prostředky - vzdělávací komiksy s př́rodovědnou tématikou a na konkrétních ukázkách přibližit jejich edukační potenciál. V návaznosti jsou uvedeny i př́íklady, jak tyto netradiční prostředky efektivně implementovat do vlastní přírodovědné výuky.

\section{NET-GENERACE ŽÁKŮ A JEJÍ SPECIFICKÉ VZDĚLÁVACÍ POTŘEBY}

Přestože STEM vyučovací předměty mají ve vzdělávání klíčovou pozici, musejí v současnosti čelit přetrvávajícímu poklesu zájmu ze strany žáků. Aktuální vývoj přírodovědného a matematického vzdělávání je však významně ovlivňován i dalším aspektem, který souvisí s proměnami vzdělávacího a sociálního prostředí dnešních žáků. Konkrétně jde o to, že školy v současnosti vzdělávají žáky, kteří se narodili a dospívají v novém tisíciletí, tedy době, kdy je internet a jeho aplikace nedílnou součástí každodenního života. Intenzivně se rozvíjí i informační technologie (počítače, tablety, mobilní telefony aj.), s nimiž se žáci setkávají každodenně na různých místech (ve škole i během volnočasových aktivit). Současní žáci jsou tak stále častěji považováni za tzv. Net-generaci ${ }^{4}$ (Tapscott, 1999; Ab Hamid, Akhir \& Nazir, 2015).

Je známé, že každá generace se od té předchozí liší například stylem oblékání, mluvou apod. U Net-generace se však jedná o závažnější druh odlišnosti, který vede ke změně jejího učebního stylu a ovlivňuje kvalitu jejího vzdělávání (viz Aviles \& Eastman, 2012; Hernaus \& Pološki Vokic, 2014; Oblinger \& Oblinger, 2005; Romero, Guitert, Sangrà \& Bullen, 2013; Tapscott, 2009). V rámci STEM vzdělávání se tak lze setkat s názory, které se vzrůstající intenzitou vyzývají k přehodnocení pohledu na zákonitosti edukačního procesu. Teorií vzdělávání, jež si v tomto ohledu

\footnotetext{
${ }^{1}$ Angl. Science, Technology, Engineering and Mathematics.

${ }^{2}$ Angl. evidence based.

${ }^{3}$ Pojem blended-learning označuje specifickou formu výuky, při níž dochází k prolínání standardního vyučování a e-learningu.

${ }^{4}$ Terminologie sloužící k pojmenování Net-generace se vyvíjí, v současnosti se tak lze setkat i s označením „generace Y“ (Wimms \& Berge, 2009), „generace Z“, „digital natives“ (Bennett, S., Maton, K. \& Kervin, L., 2008), či „Millennials“ (Martin \& Tulgan, 2001) atd.
} 
získává nejvíce pozornosti, je konektivismus (Siemens, 2004, 2014; Downes, 2012, 2015), který ke vzdělávání přistupuje v kontextu informační exploze a rozmachu moderních ICT technologií. Východiskem konektivismu je přesvědčení, že poznatky, se kterými se žáci v současnosti setkávají, není možné uchopovat jako trvalé „entity“, nýbrž je nutné s nimi pracovat jako se „sloučeninami“, které se proměňují, nebot jejich části pocházejí z různých oblastí lidského poznání. Učení dle konektivismu spočívá ve vyhledávání, zpracovávání a sdílení informací, přičemž výsledkem tohoto procesu jsou komplexní myšlenkové sítě propojující subjektivně důležité poznatky různé povahy a modality. $\mathrm{V}$ důsledku tak může docházet k oslabování vnější regulace při učení a naopak většímu důrazu na žáky, aby se sami podíleli na usměrňování průběhu vlastního vzdělávání (Kop \& Hill, 2008: s. 9).

Jak již bylo zmíněno, příslušníci Net-generace vyrůstají v prostředí přebujelém informacemi, přičemž podstatná část z nich má vizuální podobu. Dokáží proto integrovat obrazy, zvuk a text přirozenou cestou a snadno se také vyjadřují pomocí obrázků. Čtení a porozumění dlouhým textům je pro ně však obtížné. Pokud pro ně téma není zajímavé, přeskakují pasáže a snaží se rychle dospět ke konci (Grunwald, 2003). Zásadní aspekt konektivistické výuky proto představují didaktické prostředky, jež jsou blízké zájmům žáků a stimulují jejich učební aktivity. Příslušníci Net-generace dokáží koordinovat více učebních aktivit najednou (tzv. multiprocesing), zároveň však obtížněji udržují pozornost a poměrně rychle se přestávají zabývat aktivitami nebo informacemi, o které nemají zájem nebo které jim neposkytují rychlou odezvu. Úlohy vyžadující dlouhodobější koncentraci anebo abstraktní myšlení (např. čtení či porozumění složitým pasážím) jim proto mohou činit obtíže. Charakteristické je pro příslušníky Net-generace také to, že při osvojování a produkování poznatků mají potřebu být propojeni s komunitou obdobně smýšlejících jedinců (Ab Hamid, Akhir \& Nazir, 2015). Školní výuka, resp. působení učitele, pro ně proto může ztrácet pozici hlavního zprostředkovatele informací, a do určité míry se tak stávat jen širším kontextem sloužícím k potvrzování nebo vyvracení vlastních poznatků.

Učební návyky Net-generace jsou však specifické i v oborově didaktickém pohledu. Výuka přírodovědných předmětů vychází z exaktních vzdělávacích obsahů, závazných instrukcí či přesných měření, jež jsou nezbytné např́klad př̀i práci s laboratorními zařízeními anebo manipulaci s rizikovými prostředky (např. chemikáliemi). Tento rigidní přístup $\mathrm{v}$ určitých oblastech př́rodovědné výuky ale žákům Net-generace nemusí vždy vyhovovat, nebot' při učení inklinují k rychlejším, zpravidla však kognitivně méně náročným postupům (např. tzv. pokus-omyl). Vedle nároků na plánování a organizaci př́rodovědné výuky, tak Net-generace může svými učebními návyky ovlivňovat i výběr a využívání didaktických prostředků. Př́islušníci Net-generace oceňují didaktické prostředky, u nichž převažuje vizuální komponenta nad textovou. Vyhovuje jim také práce s elektronickými prostředky (např. tablety, interaktivní tabule ad.) a využívání ICT ve výuce. Tyto prostředky jim totiž umožňují převzít kontrolu nad tempem a průběhem učebního procesu. Naopak k tradičním didaktickým prostředkům, obsahujícím dlouhé textové pasáže, se obvykle staví rezervovaně či dokonce odmítavě. ${ }^{5}$

\footnotetext{
${ }^{5}$ Uvedené skutečnosti potvrzuje Grunwald (2003), podle nějž žáci Net-generace dosahují vyšších učebních výkonů, pokud je jim přírodovědné učivo zprostředkováváno formou, která odpovídá jejich přístupu k získávání informací. Podobně Trnová (2012) ve své studii zjistila, že jsou-li při instruktáži, jak bezpečně pracovat v laboratoři, použity netradiční didaktické prostředky (např. právě komiksy), žáci se s bezpečnostními předpisy více ztotožňují a následně je také důsledněji dodržují.
} 
V přírodovědné výuce současné Net-generace žáků se tak stále častěji objevují didaktická média umožňující sdílení (sociální sítě) anebo společnou tvorbu vzdělávacích obsahů (Wiki apod.). Konkrétně se jedná např. o tzv. Web 2.0, který je již jedno desetiletí oblíbeným prostorem pro výměnu nápadů týkajících se nejen přírodovědné výuky. Objevují se však

i náznaky o nastupujícím Webu 3.0, který má mít mnoho nových funkcí a aplikací. V současnosti jsou však odborníky za slibné vzdělávací prostředky považovány i komiksy a jejich různé varianty. Komiksy lépe odpovídají vysoké míře vizuální gramotnosti současných žáků. Obsahují jen „nezbytné“ množství textu, a tak mohou napomáhat porozumění př́rodovědné problematice a zároveň sloužit jako vysoce motivační prvek. V zahraničí je využívání komiksů jako didaktických prostředků poměrně běžné, v domácím prostředí se však stále jedná o záležitost poměrně ojedinělou.

\section{VYMEZENÍ KOMIKSU JAKO DIDAKTICKÉHO PROSTŘEDKU}

I když je považován za fenomén moderní doby, počátky komiksu sahají už do období antiky a středověku. Zde původně sloužil pro vyjádření posměchu či společenské znevažování nepopulárních osob (Munier, 2000: s. 21) ${ }^{6}$. Avšak s tím, jak se různé formy komiksu stávaly stále propracovanější a o jejich povaze toho bylo známo více, se komiks stal médiem s nezanedbatelným sociálním vlivem (Gruenberg, 1944: s. 204)7 . V současnosti je komiks pro většinu čtenářů jednoduchým obrázkovým příběhem, který zábavnou formou připodobňuje př́běhy z oblasti fantasie či události z reálného společenského života. Rozmanitost komiksu je reflektována i v množství definic, jež jsou aktuálně k dispozici. Například podle McLouda (1993) by komiksy měly být chápány jako „... sekvenční umění sestávající z obrazů řazených za sebou... “. Hlavním kritériem je pro něj proto rozsah komiksu, resp. počet panelů. Ve srovnání s tím Varnum \& Gibbons (2001) považují za podstatný znak komiksu „.. . vzájemnou kombinaci obrázků a slov, umožňujicich vyprávěni určitého děje“. Nejdůležitějším rysem komiksů však je, že se uplatňují jako vizuální metafora, která zveličováním charakteristických znaků vyvolává intenzivnější a bohatší asociace, než by o znázorňovaných jevech bylo možné získat v reálné situaci (Fry, Wilson \& Overby, 2013: s. 163-164). Tato studie se při snaze o objasnění edukačního potenciálu komiksů zaměřuje na specifickou oblast, tzv. vzdělávací komiksy, jež se uplatňují při didaktickém transformování a reprezentování přírodovědných pojmů a témat (srov. Trnová, Trna \& Vacek, 2013).

\subsection{DidAKTICKÝ POTENCIÁL KOMIKSU NEJEN PRO PŘíRODOVĚDNOU VÝUKU}

Současné edukační prostředí, přebujelé rozmanitými podněty, může vést $\mathrm{k}$ tomu, že žáci mají při snaze o porozumění př́rodovědným fenoménům obtíže s koncen-

\footnotetext{
${ }^{6}$ Podrobněji je historie používání komiksu jako didaktického prostředku popsána např. ve studii Vacka a Janka (2014: s. 40-41).

${ }^{7}$ Podle Aldama (2012: s. 362) k oblíbenosti komiksu přispívá i to, že si jeho př́znivci mohou vybírat z množství dostupných druhů a témat. V oblasti přírodovědného vzdělávání jsou obzvláště zajímavá ty, jež umožňují demonstrovat různé fyzikální jevy (ovládání elektrických výbojů, magnetismu), či biologické anebo chemické procesy (tělesné mutace, používání výbušnin, laseru ad.).
} 
trací na klíčové poznatky a na jejich utřídění do celistvého systému. Komiks jako didaktický prostředek může tuto situaci zmírňovat tím, že díky svým výrazovým prostředkům dokáže abstraktní př́rodovědné jevy transformovat do podoby, jež je pro žáky vstřícná a lépe uchopitelná. Důležitý aspekt v tomto ohledu představuje výrazně zprostředkující charakter komiksu (Peltz, 2013: s. 9). Ústřední pojmy jsou v komiksech zvýrazněny, např. obrazovými figurami, stylem písma, a při osvojování přírodovědných pojmů tak mohou sloužit jako kognitivní lešení (Versaci, 2001: s. 52). Obrazová povaha komiksů napomáhá rychlejšímu a často i přesnějšímu vhledu do znázorňované problematiky, může proto lépe vyhovovat vzdělávacím potřebám současných žáků (Short \& Reeves, 2009: s. 417; Wolf, Coats, Enciso \& Jenkins: 2010, s. 258). Textová složka je ale pro didaktické fungování komiksu neméně důležitá. Vyskytuje se obvykle ve formě tzv. bublin nebo jako záhlaví panelu (Meskin, 2013: s. 582). Dokresluje smysl zobrazovaného, a je proto zásadní pro celkové pochopení informace obsažené v komiksu. Méně zřejmou, avšak neméně důležitou součástí komiksu je sémantický prostor mezi panely, který čtenáři umožňuje domýšlet, co a jak se v komiksu odehrává. Jeho prostřednictvím se tak žáci mohou aktivně zapojovat do interpretace komiksu a jeho přeměňování v ucelený příběh (Tensuan, 2014: s. $415-416)$.

Komiksové ztvárnění učiva je pro žáky atraktivní a vzbuzuje jejich zájem, proto edukační přínos komiksů spočívá vedle konektivistického poznávání jevů také v rovině motivace.

I složitější vzdělávací obsahy se jeví živější a emocionálně přijatelnější. Jsou-li komiksy správně koncipovány, může jejich zapojování do výuky přispívat ke snižování kognitivní zátěže žáků (srov. Mayer, 2011: s. 427). Při práci s komiksem mohou žáci postupovat vlastním tempem, osvojovaní nových informací tak mají pod kontrolou a o vzdělávacích obsazích tak mohou snáze uvažovat v souvislostech. Komiksy jsou př́ležitostí i pro učitele, jak se dozvědět více o světě, ve kterém se žáci pohybují ve škole i mimo školu (Williams, 2008: s. 18). I když nemusí být přítomen vždy, důležitou součástí komiksu je humor (Hempelmann \& Samson, 2008: s. 609-611). V komiksech se humor uplatňuje různými způsoby, jako výskyt překvapivých anebo zdánlivě nesourodých prvkư ${ }^{8}$, jejichž vyřešení vyžaduje myšlenkové úsilí a nejde jen o relaxační pobavení. Případně jako prvek napomáhající úniku před psychickým tlakem či uvolnění potlačovaných pocitů, jež se

v jedinci nahromadily (např. při zvládání obtížného učiva). Ve specifických nevhodných př́padech se humor v komiksech vyskytuje i v negativní podobě, např. jako vyjádření převahy, či s cílem někoho zesměšnit (srov. Šed’ová, 2013: s. 24). Podle Cohena (2013: s. 427-430) humorné komiksy zároveň představují efektivní způsob, jak ve výuce pracovat s citlivými, či kontroverzními tématy jako je např. (násilí, xenofobie, závislosti, sexuální tématika ad.).

\section{ANALÝZA HLAVNÍCH TYPŮ KOMIKSŮ A POROVNÁNÍ JEJICH EDUKAČNÍHO POTENCIÁLU}

V návaznosti na teoretické ukotvení jsou dále prezentovány poznatky vyplývající z námi realizovaného šetření, jehož cílem bylo na konkrétních příkladech přiblížit edukační potenciál vzdělávacích komiksů pro přírodovědnou výuku. Postup šetření byl usměrňován výzkumnými otázkami: 1) Jak se konkrétně projevuje edukační po-

\footnotetext{
${ }^{8}$ Často se jedná o různé formy nadsázky, imitace či parodie.
} 
tenciál komiksů při zprostředkovávání přírodovědných konceptů? 2) Jaké silné a slabé stránky komiksy vykazuji ve srovnání s ostatnimi didaktickými prostředky? Poznatky byly získány prostřednictvím obsahové analýzy, zaměřující se na charakteristické typy vzdělávacích komiksů (viz dále).

\subsection{SCIENCE CARTOON}

Nejjednodušším typem komiksu je tzv. science cartoon. Jedná se obvykle o jeden samostatný panel, jež se na první pohled neodlišuje od běžných učebnicových ilustrací (obr. 1). Jeho podstatou je obvykle humorné, satirické či ironické reprezentování určitého jevu. Jádro science cartoonu tvoří obrazové sdělení, doplněné $\mathrm{v}$ př́ípadě potřeby krátkým textem konkretizujícím zprostředkovávanou informaci. Šiře textového sdělení může být podmíněna také věkem žáků či očekávaným způsobem využití komiksu ve výuce (resp. výukových fázích).

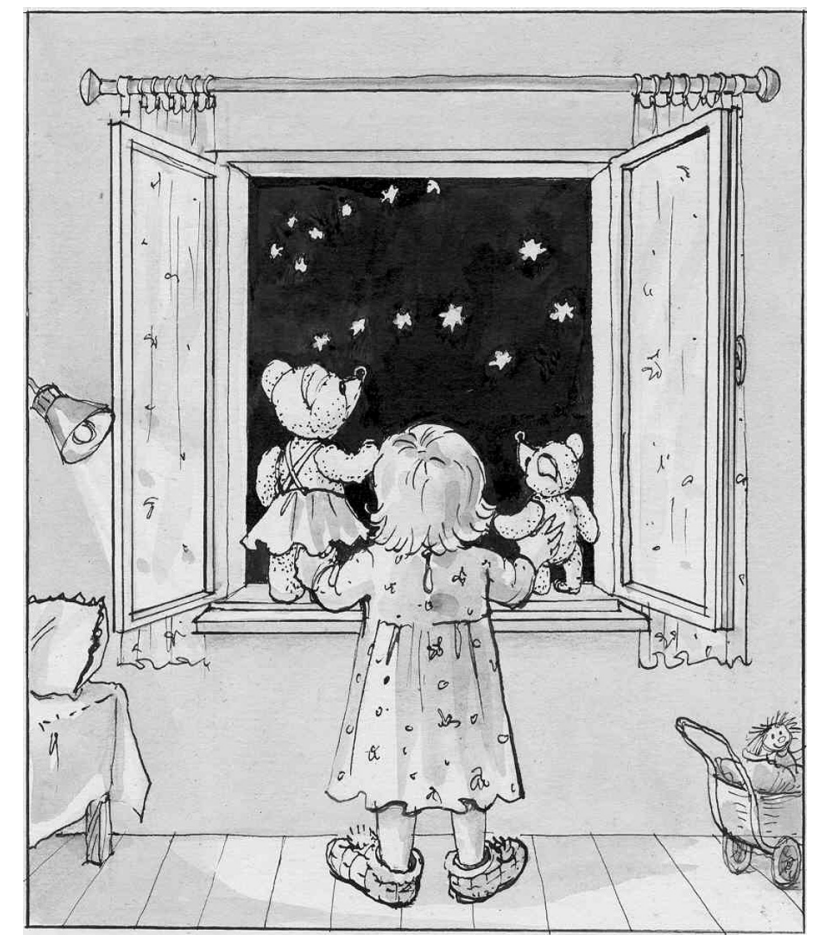

Zdroj: autorský obrázek

Obr. 1: Science cartoon; souhvězdí Velké medvědice a Malého medvěda

\section{ANALÝZA UKÁZKY NA OBRÁZKU 1}

Jedná o př́klad jednoduchého komiksu transformujicího přírodovědné učivo o souhvězdích do podoby žákům významově blízké reprezentace. Konkrétně jde o vytvoření významového propojení mezi dvěma významnými obtočnovými souhvězdími severní oblohy: Velké medvědice (Ursa Major) a Malého medvěda (Ursa Minor) a jejich sémanticky blízkými dětskými hračkami (dvojice plyšových medvědü - malý medvídek a jeho větši medvědí maminka). Přičemž za charakteristický znak komiksu je možné považovat zdůrazněni humorné stránky sdělení. Smyslem paralely je podpořit zapamatování zmiňovaných souhvězdi a také prohloubit základní orientaci žáki $v$ souhvězdích. Uplatnění tohoto komiksu se nabizí zejména na primárním a nižšim sekundárním stupni vzdělávání, čemuž odpovídaji $i$ výrazové prostředky daného 
komiksu - jednoduchá, ale realistická kresba se snadno rozpoznatelnými detaily. Zajimavostí je absence textu v komiksu, který není potřebný, ale může být doplněn učitelem. Vzhledem k uvedeným charakteristikám se uplatnění komiksu nabízi např́klad v motivačni fázi výuky.

\subsection{SCIENTOON}

Populárním typem komiksu je tzv. scientoon. Podobně jako u předcházejícího typu je i jeho úkolem didaktická transformace přírodovědných fenoménů do žákům srozumitelnější podoby. Podstata komiksového sdělení je zde ale zprostředkována významnou textovou složkou, jež objasňuje anebo na pravou míru uvádí informace o příslušném prř́rodovědném jevu (srov. Tatalovic, 2009: s. 5). Význam obrazové části komiksu potom spočívá v tom, že humornou, resp. satirickou cestou konkretizuje textovou část, a přibližuje tak daný jev představám a výrazovým prostředkům žáků (obr. 2). Ve srovnání s ostatními typy komiksů je pro scientoon charakteristický důraz na oborovou správnost (kontext oboru).

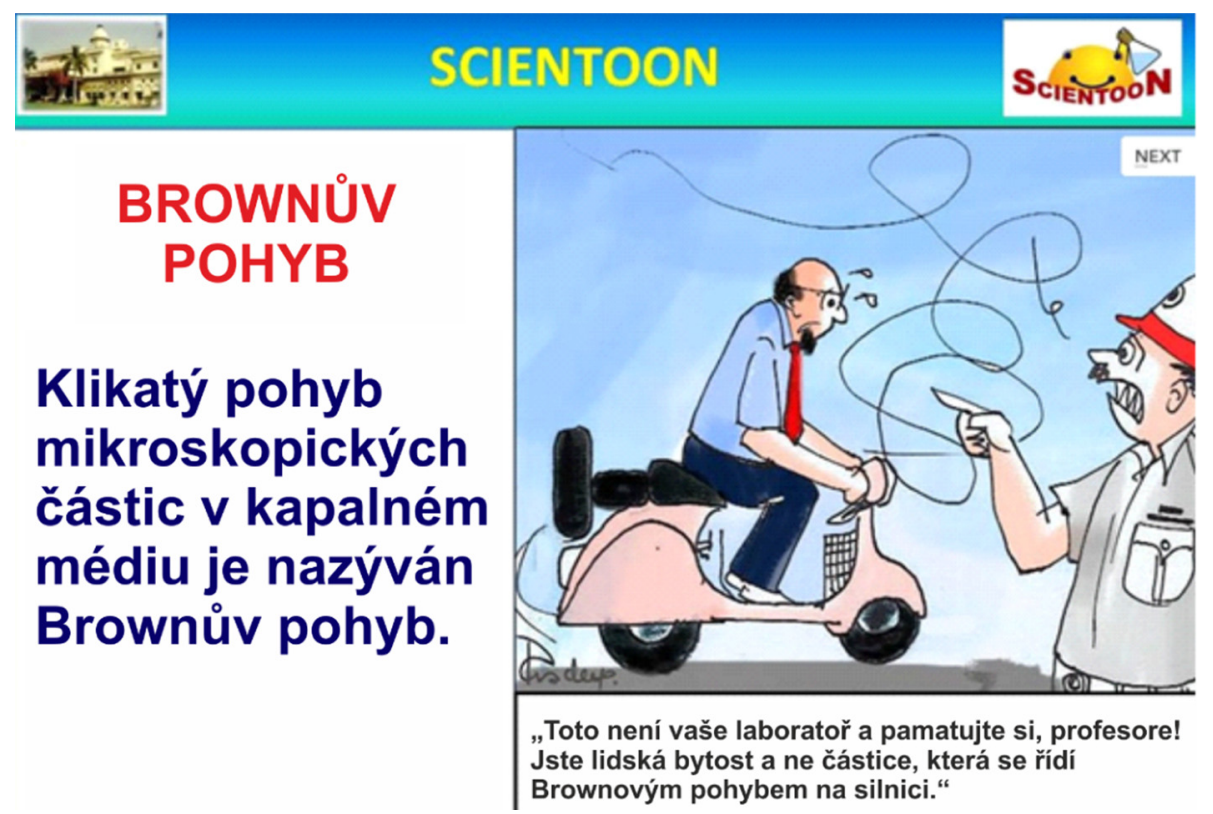

Zdroj: upraveno dle Scientoons Pradeep Srivastava Dostupné z http://www.scientoon.com

Obr. 2: Scientoon; Zákonitosti Brownova pohybu

\section{ANALÝZA UKÁZKY NA OBRÁZKU 2}

Podstatou komiksové ukázky je objasnění jednoho ze základních fyzikálních jevi Brownova termického pohybu molekul. Sémantický význam komiksového sdělení $v$ tomto případě nese textová složka nabizejíci žákům definici Brownova pohybu, a napomáhající tak proniknutí $k$ podstatě jevu. Obrazová část komiksu je vystavěna na základě humorné analogie a vyjadřuje paralelu mezi neuspořádaným pohybem molekuly a nesprávným pohybem chaotického profesora během silničního provozu. Analogie mezi textovou a obrazovou komponentou je v tomto prípadě volná, nebot' se zde jedná o značnou nadsázku. Vzhledem $k$ obsahové $i$ formální stránce je daný komiks vhodný spiše pro žáky vyššího stupně sekundárního vzdělávání. Jeho využití se nabizi např́klad v expozični fázi výuky fyziky anebo chemie, může však být zapojen i ve výukové fázi opakování. 


\subsection{CONCEPT CARTOON}

Velká míra pozornosti je v současnosti věnována i tzv. concept cartoonu, jenž obvykle sestává ze samostatného obrazového panelu, který však lze při podrobnějším pohledu rozdělit do dílčích, navzájem provázaných částí. Podstatou tohoto typu komiksu je zprostředkovávání alternativních pohledů a názorů týkajících se určitého př́rodovědného jevu. Typický obsah concept cartoonu tak představuje skupinová diskuse postav směřující k objasnění daného jevu (obr. 3). Charakteristické jsou pro něj i následující znaky: správné řešení se obvykle nachází mezi alternativami, přičemž není upřednostňováno pouze jedno řešení, porozumění komiksovému sdělení vyžaduje zapojení osvojených znalostí žáka, a také jeho zkušenosti z každodenního života (srov. Naylor \& Keogh, 2013: s. 4). Obrazová a textová složka je u tohoto typu komiksu navzájem propojena, na utváření významu sdělení se proto podílí stejným dílem.

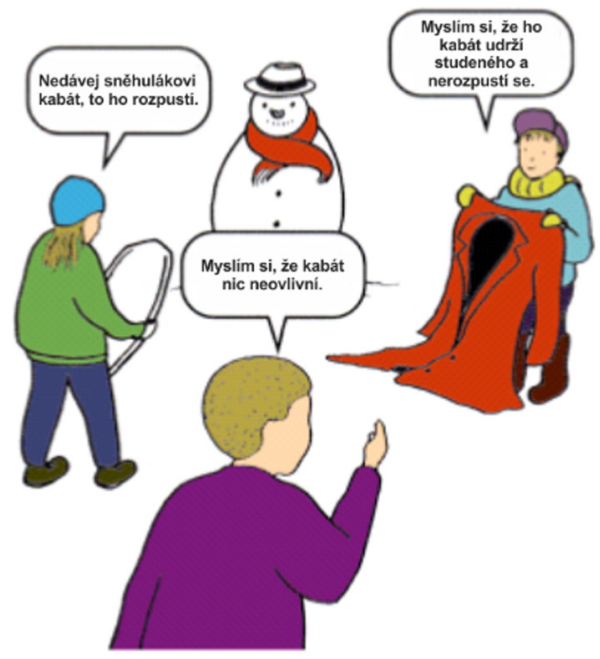

Zdroj: upraveno dle Millgate House Publishing Ltd. Author: Brenda Keogh and Stuart Naylor

Dostupné z http://www.millgatehouse.co.uk

Obr. 3: Concept cartoon: Změna skupenství

\section{ANALÝZA UKÁZKY NA OBRÁZKU 3}

Ukázka tohoto komiksu se váže ke známému fyzikálními ději - změně skupenství. Tento jev je zde reprezentován na přikladu situace blizké každodenním zkušenostem žáki̊ - táni sněhuláka. Textová část komiksového sděleni sestává z několika výroku odrážejicích alternativní pohledy na podstatu zkoumaného jevu. Zatímco obrazová část uvedené výroky zasazuje do lépe představitelného kontextu. Úkolem je vyvolat $u$ žáků diskusi směřujici $k$ nalezeni správného řešeni daného př́rodovědného jevu. Žáci jsou zároveň podněcováni, aby na základě konfrontace s nabizenými výroky doplnili vlastni vysvětlení jevu. Smyslem je externalizace prekonceptů a znalostí žáku a jejich připadné napraveni a rozšírení. Uplatněni tohoto komiksu se nabizi na nižšim stupni sekundárního vzdělávání, konkrétně v expoziční fázi výuky anebo během opakování.

\subsection{COMICS STRIP}

Propojením samostatných panelů do komiksového pásu vzniká tzv. comics strip. Př́nosem tohoto formátu je kontinuita a jasnější narativita prezentovaného tématu. 
Dominantní je obrazová složka komiksu, přírodní jevy tak mohou být rozloženy do dílčích, avšak navzájem provázaných sekvencí (obr. 4). V konečném důsledku tak může být podpořeno hlubší porozumění přírodnímu jevu. Komiksové pásy mohou při transformování přírodních jevů nabývat humorné, ale i seriózní formy (srov. Vacek \& Janko, 2014: s. 41).
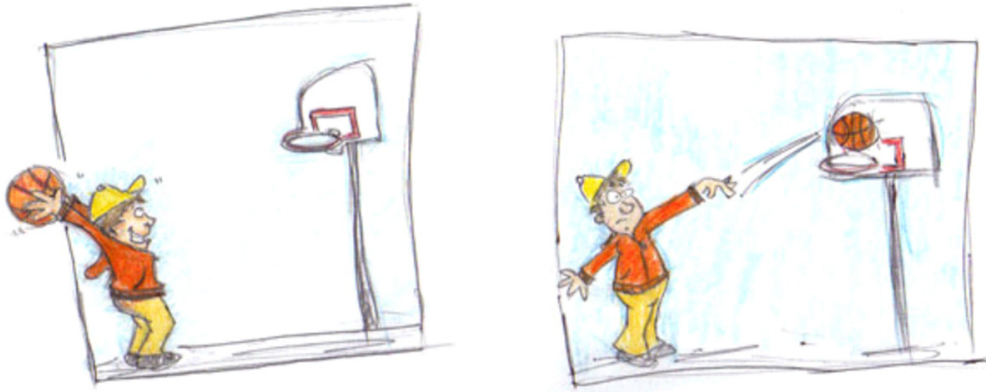

\section{Ke každé akci existuje opačná, ale stejně velká reakce!}

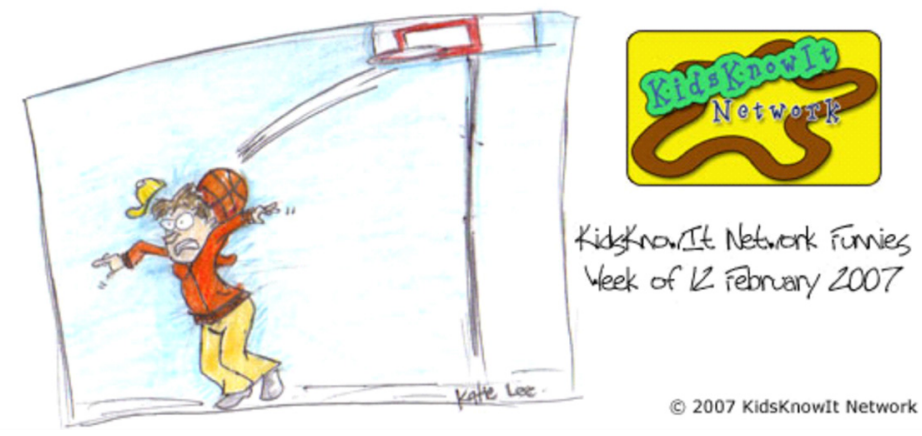

Zdroj: upraveno dle Educational Comics; Website

Dostupné z http://www.kidsknowit.com/educational-comics/2007-02-12.php

Obr. 4: Comic strip: Akce-reakce

\section{ANALÝZA UKÁZKY NA OBRÁZKU 4}

Komiks znázorňuje fyzikální pojem akce a reakce. Konkrétně jde o transformaci této fyzikálni zákonitosti na základě humorné paralely ke sportovni aktivitě - hodu basketbalovým mičem. Obrazová část tohoto komiksu napomáhá převedení (rozfázování) fyzikálního jevu do dílčích etap a podporuje tak porozumění významu a zákonitostem daného jevu, zatímco textová část má v tomto př́padě doplňujici (identifikujicí) funkci. Výrazové prostředky tohoto komiksu předjímaji jeho uplatnění komiksu na nižšim stupni sekundárního vzdělávání. Přitom využití se nabizi v motivační, př́padně expozični fázi výuky.

\section{PřÍNOS A RIZIKA VYUŽÍVÁNÍ KOMIKSŮ V PŘÍRODOVĚDNÉ VÝUCE}

Využívání komiksů má své pozitivní i negativní stránky, jež z hlediska realizace přírodovědné výuky mohou představovat přínosy i rizika (Trnová, 2012; Middleton \& Vanterpool, 1999) Přínos komiksů jako didaktických prostředků spočívá především v podpoře poznávání a porozumění jevů současnými žáky, stejně jako v rovině jejich studijní motivace. Naopak nepromyšlené zapojování může vést k narušování pozornosti žáků. Nejasné ztvárnění komiksů přispívá k rozvoji nepřesných představ 
Tab. 1: SWOT analýza komiksu

\section{Silné stránky}

- Komiksy představují žákům blízké znázornění učiva. Obsahují názorná zobrazení přírodních jevů a minimum textu. Mohou tak lépe vyhovovat vzdělávacím návykům a specifickým vzdělávacím potřebám současné Net-generace žáků.

- Komiksy mají pro žáky značný motivační potenciál. Přírodovědné učivo znázorňují neobvyklým, mnohdy humorným, způsobem. Přispívají tak ke snižování napětí a úzkosti v náročné výuce (např. obavy z nesprávných odpovědí) a mohou napomáhat hlubšímu porozumění přírodovědným tématům (např. Özdoğru \& McMorris, 2013: s. 136-138).

- Výrazové prostředky komiksu znázorňují přírodní jevy na základě analogie. Ty tak mohou být objasňovány z různých perspektiv a zasazovány do pro žáky smysluplného kontextu. Žáci si díky tomu mohou o př́rodních jevech vytvořit bezprostřednější představu (srov. U̇ltay, 2015: s. 96).

- Komiksy dovolují, aby si žáci sami zvolili tempo osvojování nových vědomostí, a získali tak kontrolu nad učením, což může mít v důsledku pozitivní vliv na hloubku porozumění a učební výkon.

- Zapojování komiksů je v souladu s konstruktivistickým pojetím výuky. Žáci nejsou jen pasivními př́jemci znalostí, nýbrž se podílejí na jejich utváření na základě zobrazených situací v komiksech.

\section{Slabé stránky}

- Pozitivní účinky komiksů v přírodovědné výuce nejsou samozřejmostí. Předpokladem jsou kvalitně odborně a didakticky vytvořené komiksy, pedagogické zkušeností učitelů a připravenost na práci s komiksy na straně žáků.

- Přínos komiksu je podmíněn kombinací jeho obrazové a textové složky. Rozlišování podstatných a méně důležitých výrazových prostředků komiksu ale není pro žáky vždy jednoduché.

- Důležitým aspektem komiksu je také soulad mezi jeho seriózním odborným obsahem a humornou formou. Zdůrazňováním humorné složky komiksu může docházet $\mathrm{k}$ potlačení odborného obsahu a $\mathrm{v}$ konečném důsledku vést $\mathrm{k}$ nejednoznačnému sdělení (srov. DeSousa \& Medhurst, 1982: s. 47).

- Fixace jevu a jeho využití při řešení problémů se může úzce asociovat jen s určitou situací vystavěnou v komiksu. Žák může nevhodně a úzce propojit prezentovaný jev se situací znázorněnou v komiksu, což může vést $\mathrm{k}$ jeho neschopnosti zobecnit zákonitosti jevu.

- Nesprávně koncipovaný komiks (např. neúměrně zjednodušující obrazová část, nebo vědecky nesprávná textová komponenta) může vést až ke vzniku mylných představ žáků. 
Tab. 1: pokračování

\section{Příležitosti}

- Využívání komiksů v přírodovědné výuce může být poměrně různorodé. Uplatňují se například jako podněty pro věcnou diskusi vedoucí $\mathrm{k}$ prohlubování znalostí anebo napomáhající zasazování osvojovaných poznatků do kontextu každodenních zkušeností žáků. Jejich zapojování se však nabízí i v souvislosti s diagnostikou žákovských prekonceptů anebo evaluaci „badatelských aktivit“ žáků.

- Zapojováním komiksů do př́rodovědné výuky může být rozvíjeno její konstruktivistické pojetí. Poznatky v komiksech nejsou žákům předávány jako hotové (transmisivně), naopak žáci se musejí na konstruování významu prŕrodovědných jevů aktivně podílet vlastní interpretací, uplatňováním dosavadních znalostí či prostřednictvím fantazie (srov. Çil, 2014: s. 341).

- Z didaktického hlediska může práce s komiksy v přírodovědné výuce podporovat rozvíjení specifických dovedností: kritické myšlení, představivost, schopnost vyjadřování, porozumění ad. (srov. Tensuan, 2014: s. 416-417).

- Využívání komiksů může napomáhat mezipředmětovému pojetí výuky. Při práci s komiksem jsou rozvíjeny vědomosti a dovednosti z př́́slušného oboru (např. fyzika, chemie ad.), porozumění cizím jazykům, výtvarné cítění, či aktuálně také využívání ICT.

- Díky snadné dostupnosti představují komiksy důležitý prvek neformálního vzdělávání.

\section{Hrozby}

- Zjednodušování přírodovědných konceptů v komiksech může v určitých případech vést $\mathrm{k}$ odborně nepřesným sdělením. Jsou-li komiksy do výuky zapojovány bez vhodného metodického postupu (např. upřesňujících informací, řízené diskuse o obsahu komiksu), mohou u žáků (zejména těch mladších) vyvolávat nejednoznačné anebo nesprávné představy či rozvíjet stereotypy (srov. Middleton \& Vanterpool, 1999: s. 9).

- Nadměrné, neadekvátní či metodicky nesprávné zapojování komiksů do přírodovědné výuky tak může vést $\mathrm{k}$ oslabování pozitivních účinků. $\mathrm{V}$ konečném důsledku se může stát dokonce překážkou při učení.

- Přílišné zkracování nebo zjednodušování textové složky komiksu může vést k vágním a nesprávným představám nebo řešením žáků.

- Není-li kladen důraz i na textovou složku, pak nedochází k rozvoji dovednosti čtení a porozumění psanému textu a následně i problematice komiksu. 
a v důsledku způsobuje neporozumění. Naproti tomu nevhodný obsah komiksu může zprostř̌edkovávat negativní stereotypy a vyústovat až k nevhodným projevům chování. Dále proto nabízíme přehled silných a slabých charakteristik komikso̊, stejně jako přiležitostí a rizik vyplývajících z používání komiksů jako didaktických prostředků v př́rodovědné výuce.

Z uvedeného přehledu je patrné, že komiksy se mohou uplatňovat nejen jako moderní vzdělávací prostředek vyhovující Net-generaci žáků či jako motivační prvek zvyšující atraktivitu přírodovědné výuky, ale také jako inovativní zdroj informací napomáhající snadnějšímu a hlubšímu porozumění abstraktním přírodovědným pojmům. Edukační užití komiksů je v tak posledních letech cílem řešeno v řadě studií. V těchto studiích se např́́klad ukazuje, že komiksy napomáhají rozvoji dovednosti čtení a vyjadřování myšlenek písemnou formou (De Fren, 1998), řešení konfliktů (Naylor \& McMurdo, 1990) atd. V př́rodovědném vzdělávání mohou napomoci k osvojování odborné terminologie (Goldstein, 1986); vědeckých poznatků (Guttierrez \& Ogborn,1992); schopnosti řešení problémů (Jones, 1987); motivace žáků (Heintzmann, 1989), či zjištování a napravování žákovských prekonceptů (Keogh \& Naylor, 1997, 1998).

Efektivní využivání vzdělávacích komiksů ve výuce nicméně není samozřejmostí, nýbrž je podmíněno profesní přípravou učitele v práci s komiksy a také dostatečnými dosavadními zkušenostmi žáků v jejich užívání. Zásadním aspektem je zejména vhodné didaktické zpracování vzdělávacího komiksu.

\section{ZÁSADY TVORBY VZDĚLÁVACÍCH KOMIKSŮ}

Přestože jsou komiksy u žáků oblíbené, jejich tvorba a využívání ve výuce není triviální záležitostí. Měl by se na ní podílet tým odborníků zahrnující odborníka v oboru, oborového didaktika, zkušeného učitele a dobrého výtvarníka. Osvědčuje se „pilotáž“ komiksu u příslušné cílové skupiny žáků. Jako př́klad lze uvést skutečnost, že plnohodnotné porozumění sdělení komiksového pásu vyžaduje porozumění dílčím významům, jež se nacházejí v jednotlivých panelech, a jejich myšlenkové propojení v celistvý př́iběh.

Na základě poznatků popsaných v předcházejících kapitolách, dostupných výzkumů (např. Keogh \& Naylor, 1998; viz také Parsons \& Smith, 1993) a zkušenosti autorů (Trnová, 2012) je možné formulovat zásady pro tvorbu komiksů a jejich úspěšné zapojování do přírodovědné výuky:

- Př́rodovědný obsah komiksu by měl být provázán s každodenními zkušenostmi žáků z důvodu motivace a rozvoje konstruktivistických kompetencí řešit praktické problémy a situace (srov. Arrorio, 2011: s. 93-94).

- Dominantní by měla být obrazová složka komiksu. Rozsah textové části by měl být adekvátní potřebě doplnění obrazu. Text by tedy měl sloužit zejména pro dokreslení obrazové informace a měl by být dostupný pro cílovou skupinu v závislosti na úrovni jejich čtenářské gramotnosti.

- Forma komiksu by měla podporovat komunikační kompetence žáků a napomáhat rozvoji smysluplné argumentace. Pomocí alternativních pohledů, jež mohou být v komiksu zakomponovány, lze identifikovat miskoncepty žáků o př́írodních jevech a naučit žáky rozlišovat mezi existujícími alternativami řešení problémů (srov. Song, Heo, Krumenaker, \& Tippins, 2008: s. 17-18).

- Komiksy by měly být obsahově a formou neutrální (generově, sociálně aj.), aby u žáků nedocházelo ke kognitivnímu a afektovému odmítnutí komiksu. 
Nové možnosti při komiksové tvorbě vlastních výukových komiksů přinášejí ICT technologie a on-line programy, jež poskytují oporu a tvưrčí komfort i uživatelům s omezenými výtvarnými schopnostmi. Dostupné on-line jsou např́íklad kreativní programy, které umožňují tvorbu a produkci vlastních vzdělávacích komiksů. Jejich prostřednictvím však lze snadno do práce s komiksy zapojit i žáky. Ti si tak mohou obohatit přírodovědné znalosti, ale také rozššřit vnímání mezipředmětových vztahů s předměty jako výtvarná výchova, český anebo cizí jazyk. Konkrétními prŕklady těchto on-line programů jsou uživatelsky př́větivá webová prostředí s množstvím funkcí a předpřipravených „šablon“ pro tvorbu vlastních vzdělávacích komiksů9; či prostředí podporující tvorbu vzdělávacích komiksů v češtině. ${ }^{10}$ Populární jsou však i webové návody popisující principy a zásady, jak k tvorbě naučných a také zábavných komiksů správně přistupovat. Moderní alternativou jsou interaktivní komiksy, u nichž žáci mohou při řešení určitého výukového problému zasahovat do příběhové linie. ${ }^{11}$ Přehled zajímavých tipů a nápadi̊, jak využívat komiks v přírodovědné výuce, stejně jako podrobný seznam on-line prostředí pro tvorbu vlastních vzdělávacích komiksů lze nalézt i na webu. ${ }^{12}$

\section{ZÁVĚR}

Cílem příspěvku bylo představit specifickou oblast inovativních vzdělávacích prostředků - vzdělávacích komiksů a objasnit jejich edukační potenciál pro přírodovědnou výuku. Bylo zdůvodněno, že přínos tohoto u nás dosud nepř́iliš rozšiřreného didaktického prostředku je určován nejen jeho obsahem, který je atraktivní a žákům blízký, ale také výrazovými prostředky, jež jsou pro dnešní NET-generaci žáků s odlišnými poznávacími přístupy dobře srozumitelné. Přesto je využívání komiksů jako didaktických prostředků v domácím prostředí stále spíše ojedinělé. Důvodem může být, že i když jsou komisy mezi žáky oblíbené, význam jejich vzdělávacího potenciálu vyžaduje souhru více faktorů jak na straně učitele (informovanost, kreativita a nabídka vhodných komiksů), tak žáků (dosavadní zkušenosti). Vzhledem k informačnímu zaměření př́spěvku však nebyla problematika komiksu a jeho využití v př́ŕrodovědném vzdělávání popsána v celé její komplexnosti. Nebylo například zjištováno, jak potenciál komiksu jako didaktického prostředku hodnotí samotní žáci anebo učitelé, resp. jaké vlastnosti komiksů jsou pro tyto aktéry důležité z hlediska transformování přírodovědných fenoménu. Do budoucna bychom je proto plánováno se na tyto aspekty zaměřit podrobněji.

\section{PoDĚKOVÁNí}

Příspěvek byl podpořen projektem „Zaměstnáním čerstvých absolventů doktorského studia k vědecké excelenci“" (CZ. 1.07/2.3.00/30.0009), který je spolufinancován Evropským sociálním fondem a státním rozpočtem České republiky.

\footnotetext{
${ }^{9}$ Dostupné z http://www.makebeliefscomix.com/Comix/

${ }^{10}$ Dostupné z http://comicscreator.cz/

${ }^{11}$ Dostupné z http://stripgenerator.com

${ }^{12}$ Dostupné z http://www.educomics.org/
} 


\section{LITERATURA}

Ab Hamid, N. R., Akhir, R. M. \& Nazir, S. W. M. (2015). Net-generation education: Are we ready? The Macrotheme Review, 4(2), 76-89.

Aldama, F. L. (2012). Comics. In S. Bost \& F. R. Aparicio (Eds.), The Routledge companion to latino/a literature (361-374). London: Routledge.

Arrorio, A. (2011). Comics as a narative in natural science education. Western Anatolia Journal of Educational Sciences. Special Issue. Dostupné

z http://webb.deu.edu.tr/baed/giris/baed/ozel_sayi/93-98.pdf

Aviles, M. \& Eastman, J. K. (2012). Utilizing technology effectively to improve Millennials' educational performance: An exploratory look at business students' perceptions. Journal of International Education in Business, 5(2), 96-113.

Bennett, S., Maton, K. \& Kervin, L. (2008). The 'digital natives' debate: A critical review of the evidence. British Journal of Educational Technology, 39(5), 775-786.

Çil, E. (2014). Teaching nature of science through conceptual change approach: Conceptual change texts and concept cartoons. Journal of Baltic Science Education, 13(3), 339-350.

Cohen, T. (2013). Humor. In B. Gaut \& D. McIver Lopez. The Routledge Companion to Aesthetics (425-431). London: Routledge.

De Fren, M. (1988). Using cartoons to develop writing and thinking skills. Social Studies Journal, 79, 221-224.

De Sousa, M. \& Medhurst, M. J. (1982). The editorial cartoon as visual rhetoric:

Rethinking boss tweed. Journal of Visual and Verbal Languaging, 2(2), 43-52. Dostupné z http://www.downes.ca/files/books/Connective_Knowledge-19May2012.pdf

Downes, S. (2005). An introduction to connective knowledge. Dostupné z http://www.downes.ca/cgi-bin/page.cgi?post $=33034$

Downes, S. (2012). Connectivism and connective knowledge: Essays on meaning and learning networks. Stephen Downes Web. Dostupné z http://www.downes.ca/files/books/Connective_Knowledge-19May2012.pdf

Downes, S. (2015). Learning and connectivism in MOOCs. Stephen Downes Web. Dostupné z http://www.downes.ca/presentation/357

Fry, A., Wilson, J. \& Overby, C. (2013). Teaching the design of narrative visualization for financial literacy. Art, Design $\mathscr{E}$ Communication in Higher Education, 12(2), 159-177.

Goldstein, B. (1986). Looking at cartoons and comics in a New Way. Journal of Reading, 29(7), 657-661.

Gruenberg, S. M. (1944). The comics as a social force. Journal of Educational Sociology, 18(4), 204-213.

Grunwald, P. (2003). Key technology trends: Excerpts from New survey research sundings, exploring the digital generation, Educational Technology. Washington: Department of Education.

Guttierrez, R. \& Ogborn, J. A. (1992). Causal framework for analysing alternative conceptions. International Journal of Science Education, 14, 201-220.

Heintzmann, W. (1989). Historical cartoons: Opportunities to motivate and educate. Journal of the Middle States Council for Social Studies, 11, 9-13. 
Hempelmann, F. \& Samson, A. C. (2008). Cartoons: Drawn jokes? In V. Raskin (Ed.), The primer of humor research (609-640). Berlin: Walter de Gruyer.

Hernaus, T. \& Pološki-Vokic, N. (2014). Work design for different generational cohorts: Determining common and idiosyncratic job characteristics. Journal of Organizational Change Management, 27(4), 615-641.

Jones, D. (1987). Problem solving through cartoon drawing. In R. Fisher (Ed.), Problem solving in primary schools. Oxford: Basil Blackwel.

Keogh, B. \& Naylor, S. (1997). Starting points for science. Sandbach: Millgate House.

Keogh, B. \& Naylor, S. (1998). Teaching and learning in Science using Concept Cartoons. Primary Science Review, 51, 14-16.

Kop, R. \& Hill, A. (2008). Conectivism: Learning theory of the future or vestige of the past? International Review of Research in Open and Distance Learning, 9(3), 1-13.

Martin, C. A. \& Tulgan, B. (2001). Managing generation Y. Amherst, Massachusetts: HRD Press.

Mayer, R. E. (2011). Instruction based on visualizations. In Mayer, R. E.

\& Alexander, P. A. (Eds.), Handbook of research on learning and instruction (427-445). New York: Routledge.

McLoud, S. (1993). Understanding comics. Northamption: Kitchen Sink Press.

Meskin, A. (2013). Comics. In B. Gaut \& D. M. Lopes (Eds.), The Routledge companion to aesthetics (575-584). London: Routledge.

Middleton, Y. \& Vanterpool, S. M. (1999). TV Cartoons: Do children think they are real? Research Report. Dostupné z http://files.eric.ed.gov/fulltext/ED437207.pdf

Munier, G. (2000). Geschichte im Comics: Aufklärung durch Fiktion? Hannover: Unser Verlag.

Naylor, S. \& Keogh, B. (2013). Concept cartoons: What have we learnt? Journal of Turkish Science Education, 10(1), 3-11.

Naylor, S. \& McMurdo, A. (1990). Supporting science in schools. Timperley:

Breakthrough Educational Publications.

Oblinger, D. \& Oblinger, J. (2005). Educating the Net-generation. EDUCAUSE.

Dostupné z http://www.educause.edu/educatingthenetgen/

Özdoğru, A. A. \& McMorris, R. F. (2013). Humorous cartoons in college textbooks: Student perceptions and learning. Humor, 26, 135-154.

Parsons, J. \& Smith, K. (1993). Using comic books to teach. Dostupné

z http://eric.ed.gov/ERICWebPortal/contentdelivery/servlet/

ERICServlet?accno=ED363892

Peltz, A. (2013). A visual turn: Comics and art after the graphic novel. Art in Print, $2(6), 8-14$.

Romero, M., Guitert, M., Sangrà, A. \& Bullen, M. (2013). Do UOC students fit in the Net Generation profile? An approach to their habits in ICT use. The International Review of Research in Open and Distance Learning, 14(3), 158-181.

Short, J. C. \& Reeves, T. C. (2009). The graphic novel: A cool format for communicating to generation Y. Business Communication Quarterly, 72(4), 414-430. 
Siemens, G. (2004). Connectivism: A learning theory for the digital age. International Journal of Instructional Technology and Distance Learning. Retrieved on November 12, 2006. Dostupné z http://www.itdl.org/Journal/Jan_05/article01.htm

Siemens, G. (2014). Thoughts on connectivism. Dostupné

z http://www.erlenspace.org/blog/2014/thought

Song, Y., Heo, M., Krumenaker, L. \& Tippins, D. (2008). Cartoons. An alternative learning assessment. Science Scope, 31(5), 16-21.

Šed’ová, K. (2013). Humor ve škole. Brno: MUNI Press.

Tapscott, D. (1999). Growing up digital. The rise of the Net-generation. New York: McGraw-Hill.

Tapscott, D. (2009). Grown up digital: How the Net-generation is changing your world. New York: McGraw-Hill Professional.

Tatalovic, M. (2009). Science comics as tools for science education and communication: A brief, exploratory study. Journal of Science Communication, 8(4), 1-17.

Tensuan, T. (2014). Comics. In R. C. Lee (Ed.), The Routledge companion to Asian American and Pacific islander literature (415-425). London: Routledge.

Trnová, E. (2012). Komiksy ve výuce chemie. Mediału Magazine, 9(X4), 119-123.

Trnová, E., Trna, J. \& Vacek, V. (2013). The roles of cartoons and comics in science education. In M. Costa, B. Dorio, M. Kireš. International Conference on Hands-on Science2013. Educating for Science and through Science (240-244). Košice: P. J. Saafarik University.

Ültay, N. (2015). The effect of concept cartoons embedded within context-based chemistry: Chemical bonding. Journal of Baltic Science Education, 14(1), 96-108.

Vacek, V. \& Janko, T. (2014). Možnosti komiksu jako didaktického prostředku: inspirace pro př́rodovědnou výuku. Komenský, 138(4), 40-46.

Varnum, R. \& Gibbons, Ch. T. (2001). The language of comics: Word and image.

Jackson: University Press of Mississippi.

Versaci, R. (2001). How comic books can change the way our students see literature: One teacher's perspective. English Journal, 91(2), 61-67.

Williams, R. M. C. (2008). Image, text, and story: Comics and graphic novels in the classroom. Art Education, 61(6), 13-19.

Wimms, A. S. \& Berge, Z. L. (2009). Comics: they're not just for kids anymore. Chief Learning Officer. Dostupné

z http://www.clomedia.com/articles/comics_they_re_not_just_for_kids_anymore

Wolf, S., Coats, K., Enciso, P. \& C. Jenkins (Eds). (2010). The handbook of research on children's and young adult literature. New York: Routledge.

EvA TRNOVÁ, 26136@mail.muni.cz

TOMÁŠ JANKO, janko@ped.muni.cz

Josef TRNA, trna@ped.muni.cz

KAROLÍnA PEŠKovÁ, peskova@ped.muni.cz

Institut pedagogického vývoje a inovací PdF MU

Pořičí 31, Brno, 602 00, Česká republika 